\title{
Study on Determination of Standard Molar Enthalpy of Formation for Complex of Europium Chloride with Glycine and Alanine by Calorimetry
}

\author{
Bin Deng ${ }^{a}$, Haiying Huang ${ }^{b}$ and Qiangguo $\mathrm{Li}^{\mathrm{c}}$ \\ Department of Chemistry and Life Sciences, Xiangnan University, Chenzhou 423000, China
}

adbhy88@sina.com, bxnxyhy@126.com, cpchem6@126.com

\begin{abstract}
Keywords: europium complex with amino acids, thermochemistry, calorimetry, standard molar enthalpy of formation
\end{abstract}

Abstract: The ternary complex of $\mathrm{Eu}(\mathrm{Gly})_{2}(\mathrm{Ala})_{3} \mathrm{Cl}_{3} \cdot 2 \mathrm{H}_{2} \mathrm{O}(\mathrm{Gly}=$ Glycine and $\mathrm{Ala}=$ Alanine $)$ was synthesized and characterized by comparison of elementary analysis, chemical analysis, thermogravimetric analysis, and data with corresponding. The dissolution enthalpies of the $\mathrm{EuCl}_{3} \cdot 6 \mathrm{H}_{2} \mathrm{O}(\mathrm{s}), 2 \mathrm{Gly}(\mathrm{s})+3 \mathrm{Ala}(\mathrm{s})$ and $\mathrm{Eu}(\mathrm{Gly})_{2}(\mathrm{Ala})_{3} \mathrm{Cl}_{3} \cdot 2 \mathrm{H}_{2} \mathrm{O}(\mathrm{s})$ in $2 \mathrm{~mol} / \mathrm{L} \mathrm{HCl}$ solution have been measured at $298.15 \mathrm{~K}$ by isoperibol calorimeter. Based on the results, by designing a thermochemical cycle in terms of Hess' Law and through calculation, The standard molar reaction enthalpy of Europium chloride six-hydrate with Glycine and Alanine has been determined: $\Delta_{\mathrm{r}} H_{\mathrm{m}}^{\theta}(298.15 \mathrm{~K})=-51.780 \mathrm{~kJ} / \mathrm{mol}$, and the standard enthalpy of formation of $\mathrm{Eu}(\mathrm{Gly})_{2}(\mathrm{Ala})_{3} \mathrm{Cl}_{3} \cdot 2 \mathrm{H}_{2} \mathrm{O}(\mathrm{s})$ has been calculated to be $\Delta_{\mathrm{f}} H_{\mathrm{m}}^{\theta}\left[\mathrm{Eu}(\mathrm{Gly})_{2}(\mathrm{Ala})_{3} \mathrm{Cl}_{3} \cdot 2 \mathrm{H}_{2} \mathrm{O}(\mathrm{s}), 298.15 \mathrm{~K}\right]$ $=-4488.8 \mathrm{~kJ} / \mathrm{mol}$.

\section{Introduction}

Since the pioneering work of Anghileri ${ }^{[1]}$, rare-earth coordination complexes have received a great deal of attention due to their potential use in the wool dyeing industry as dyeing accelerant and in agriculture as additive because of their physiological and biochemical effects ${ }^{[2]}$. For example, plenty of experimental results have shown that the rare earth complexes, compared with many other synthetic organic drugs and transition metal complexes, are of lower toxicity and lower accumulation in the body. So far, nearly Tens of millions of rare-earth compounds with L-amino acids have been reported, many research activities have focused on the syntheses of these coordination complexes and their relevant applications. It is necessary to obtain basic thermodynamic properties as the basis for theoretical research and industrial design when they are synthesized and developed industrially. However, until now, the basic thermodynamic properties of rare-earth coordination complexes were reported in literature rarely. Liu et al ${ }^{[3]}$. reported synthesis and characterization of the solid ternary complexes of rare earths with glycine and alanine, but the thermodynamic properties of $\mathrm{Eu}(\mathrm{Gly})_{2}(\mathrm{Ala})_{3} \mathrm{Cl}_{3} \cdot 2 \mathrm{H}_{2} \mathrm{O}(\mathrm{s})$ have not been reported. To further research the complex, There needs to determine its basic thermochemical parameters. Therefore, with solution-reaction isoperibol calorimeter which is a broad and versatile technique that has the advantages of being rapid, accurate, economical, and convenient, the dissolution enthalpies of $\mathrm{EuCl}_{3} \cdot 6 \mathrm{H}_{2} \mathrm{O}(\mathrm{s}), 2 \mathrm{Gly}(\mathrm{s})+3 \mathrm{Ala}(\mathrm{s})$ and $\mathrm{Eu}(\mathrm{Gly})_{2}(\mathrm{Ala})_{3} \mathrm{Cl}_{3} \cdot 2 \mathrm{H}_{2} \mathrm{O}(\mathrm{s})$ in $2 \mathrm{~mol} / \mathrm{L} \mathrm{HCl}$, were determined. By designing a thermochemical cycle according to Hess' law, the molar enthalpy of the following reaction was calculated: $\mathrm{EuCl}_{3} \cdot 6 \mathrm{H}_{2} \mathrm{O}(\mathrm{s})+2 \mathrm{Gly}(\mathrm{s})+3 \mathrm{Ala}(\mathrm{s})=\mathrm{Eu}(\mathrm{Gly})_{2}(\mathrm{Ala})_{3} \mathrm{Cl}_{3} \cdot 2 \mathrm{H}_{2} \mathrm{O}(\mathrm{s})+4 \mathrm{H}_{2} \mathrm{O}(\mathrm{l})$ and the standard molar enthalpy of formation of $\mathrm{Eu}(\mathrm{Gly})_{2}(\mathrm{Ala})_{3} \mathrm{Cl}_{3} \cdot 2 \mathrm{H}_{2} \mathrm{O}(\mathrm{s})$ was estimated.

\section{Experimental Section}

Preparation. All regents were analytical grade and used without any further purification. The synthesis and purification of $\mathrm{Eu}(\mathrm{Gly})_{2}(\mathrm{Ala})_{3} \mathrm{Cl}_{3} \cdot 2 \mathrm{H}_{2} \mathrm{O}$ was carried out as described in the literature $^{[3]}$. In a typical synthesis of $\mathrm{Eu}(\mathrm{Gly})_{2}(\mathrm{Ala})_{3} \mathrm{Cl}_{3} \cdot 2 \mathrm{H}_{2} \mathrm{O}(\mathrm{s}), 16.1 \mathrm{mmol}$ of $\mathrm{EuCl}_{3} \cdot 6 \mathrm{H}_{2} \mathrm{O}(\mathrm{s})$ was dissolved in $65 \mathrm{~mL}$ water, which was then added dropwise into $45 \mathrm{~mL}$ water solution (the $\mathrm{pH}$ was adjusted to 5.0 by adding a suitable amount of $\mathrm{NaOH}$ ) possessing $30 \mathrm{mmol}$ Glycine and $45 \mathrm{mmol}$ 
Alanine. The reaction mixture was refluxed for $2 \mathrm{~h}$ under vigorous magnetic stirring, and then cooled to room temperature. After overnight deposition and air pump filtration, a solid complex was obtained. The product was washed alternately with ethanol, acetone and water until no $\mathrm{Cl}^{-}$was detected in the filtrate. After that, the product was dried in a vacuum desiccator at $60{ }^{\circ} \mathrm{C}$ until its mass remained constant.

Characterization. Elemental analyzer (Perkin-Elmer $2400 \mathrm{CHN}$, USA), thermogravimetrie analyzer (Perkin-Elmer TG6, at a heating rate of $10{ }^{\circ} \mathrm{C} / \mathrm{min}$ in flowing $\mathrm{N}_{2}$, USA), Abbe refractometer (WAY, Shanghai, China), ultraviolet-visible spectrotometer (U-3010, HITACHI, Japan), solution-reaction isoperibol calorimeter (SRC 100, constructed by the thermochemical laboratory of Wuhan University, China), conductance (DDS-12A, Shanghai,China).

\section{Results and discussion}

The chemical composition of the synthetic sample was determined by elemental analysis for $\mathrm{C}, \mathrm{H}$, and $\mathrm{N}$, by EDTA titration for $\mathrm{Eu}^{+[4]}$, by mercury salt titration for $\mathrm{Cl}^{-}$, and by difference and TG-DTG curve for $\mathrm{H}_{2} \mathrm{O}$. The analysis results proved that the composition of the complex was $\mathrm{Eu}(\mathrm{Gly})_{2}(\mathrm{Ala})_{3} \mathrm{Cl}_{3} \cdot 2 \mathrm{H}_{2} \mathrm{O}$.

The results of solution-reaction isoperibol calorimeter and calibration were as follows. The principle and structure of the solution-reaction isoperibol calorimeter (SRC 100) were described in detail in reference ${ }^{[5]}$. The calibration of the calorimeter was tested by measuring the dissolution enthalpies of THAM (NBS 742a, U.S.A.) in $0.1000 \mathrm{~mol} / \mathrm{L} \mathrm{HCl}$ and $\mathrm{KCl}$ (calorimetric primary standard) in water, at $298.15 \mathrm{~K}$. The mean dissolution enthalpies were $-29776 \pm 16 \mathrm{~J} / \mathrm{mol}$ for THAM and $17597 \pm 17 \mathrm{~J} / \mathrm{mol}$ for $\mathrm{KCl}$, the results were in conformity with the published data $\left(-29766 \pm 31.5 \mathrm{~J} / \mathrm{mol}\right.$ for $\mathrm{THAM}^{[6]}$ and $17536 \pm 9 \mathrm{~J} / \mathrm{mol}$ for $\left.\mathrm{KCl}^{[7]}\right)$, respectively. The uncertainties of both values were less than $0.5 \%$. This showed that the device used in this experiment for measuring the enthalpy of solution was reliable.

The results of dissolution enthalpies were as follows. The method of dissolution enthalpies determination for the samples was the same as that for the calibration of the calorimeter with THAM and $\mathrm{KCl}$. The temperature of the calorimetric experiment was set at $298.15 \mathrm{~K}$. During each electrical energy calibration, the electrical current $(I)$ was set at $10.0016 \mathrm{~mA}$, and the resistance of the electrical heater was $1003.6 \Omega$.

$\mathrm{Eu}(\mathrm{Gly})_{2}(\mathrm{Ala})_{3} \mathrm{Cl}_{3} \cdot 2 \mathrm{H}_{2} \mathrm{O}$ could be regarded as the product of the following reaction(1), and the thermochemical cycle was designed as Fig. 1. The calorimetric results of reactions (2), (3) and (4) were listed in Table 1. The inevitable heat transfer and the generation of heat by friction were compensated and the corrected temperature $\Delta T^{*}$ change could be obtained according to Dickinson's method (the equal area method) ${ }^{[8]}$.

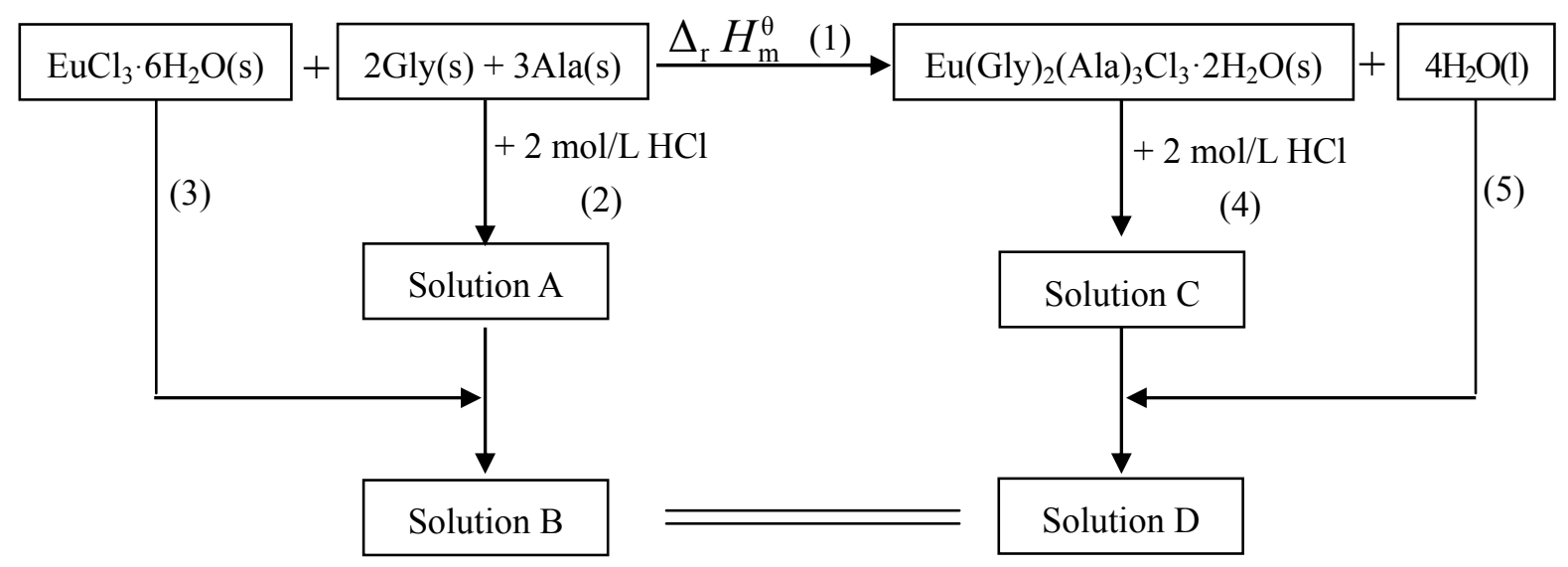

Fig. 1 Thermochemical cycle of the coordination reaction 
Table 1 Dissolution enthalpies of $\left[2 \mathrm{Gly}(\mathrm{s})+3 \mathrm{Ala}(\mathrm{s}),\left[\mathrm{EuCl}_{3} \cdot 6 \mathrm{H}_{2} \mathrm{O}(\mathrm{s})\right]\right.$ and $\left[\mathrm{Eu}(\mathrm{Gly})_{2}(\mathrm{Ala})_{3} \mathrm{Cl}_{3} \cdot 2 \mathrm{H}_{2} \mathrm{O}(\mathrm{s})\right]$ in $2 \mathrm{~mol} / \mathrm{L} \mathrm{HCl}$ at $298.15 \mathrm{~K} .(\mathrm{R}=1003.6 \Omega, \mathrm{I}=10.0016 \mathrm{~mA})$

\begin{tabular}{|c|c|c|c|c|c|c|c|}
\hline System & No. & $m / g$ & $\Delta E_{\mathrm{g}} \mathrm{mV}$ & $\Delta E_{\mathrm{e}} / \mathrm{mV}$ & $t / s$ & $Q_{\mathrm{s}} / \mathrm{J}$ & $\Delta_{\mathrm{s}} H_{\mathrm{m}}^{\theta} /(\mathrm{kJ} / \mathrm{mol})$ \\
\hline \multirow{5}{*}{$\begin{array}{l}2 \mathrm{Gly}(\mathrm{s})+3 \mathrm{Ala}(\mathrm{s}) \text { in } 2 \mathrm{~mol} / \mathrm{L} \\
\mathrm{HCl}\end{array}$} & 1 & 0.4186 & 5.650 & 6.560 & 366.8 & 33.2449 & 33.142 \\
\hline & 2 & 0.4181 & 5.820 & 6.000 & 342.0 & 33.3040 & 33.249 \\
\hline & 3 & 0.4188 & 5.610 & 6.120 & 355.0 & 33.2423 & 33.132 \\
\hline & 4 & 0.4183 & 5.640 & 6.010 & 346.8 & 33.2490 & 33.168 \\
\hline & 5 & 0.4118 & 5.690 & 6.140 & 356.6 & 33.2691 & 33.198 \\
\hline \multicolumn{8}{|c|}{ 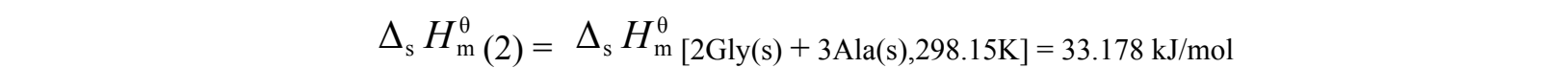 } \\
\hline \multirow{5}{*}{$\begin{array}{c}\mathrm{EuCl}_{3} \cdot 6 \mathrm{H}_{2} \mathrm{O}(\mathrm{s}) \text { in } \\
2 \mathrm{Gly} \cdot 3 \mathrm{Ala} \cdot 2 \mathrm{~mol} / \mathrm{L} \mathrm{HCl}\end{array}$} & 1 & 0.3633 & 7.355 & 7.426 & 690.6 & -68.6680 & -69.256 \\
\hline & 2 & 0.3615 & 7.370 & 7.574 & 700.8 & -68.4601 & -69.390 \\
\hline & 3 & 0.3642 & 7.312 & 7.595 & 711.2 & -68.7386 & -69.156 \\
\hline & 4 & 0.3609 & 7.394 & 7.401 & 681.5 & -68.3522 & -69.396 \\
\hline & 5 & 0.3651 & 7.301 & 7.637 & 718.4 & -68.9483 & -69.196 \\
\hline \multicolumn{8}{|c|}{ 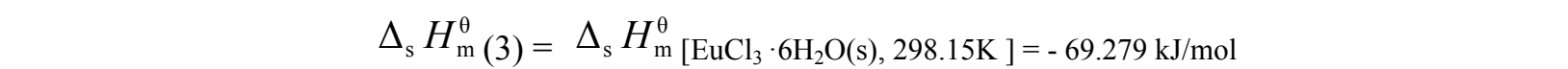 } \\
\hline \multirow{5}{*}{$\begin{array}{c}\mathrm{Eu}(\mathrm{Gly})_{2}(\mathrm{Ala})_{3} \mathrm{Cl}_{3} \cdot 2 \mathrm{H}_{2} \mathrm{O} \text { in } \\
2 \mathrm{~mol} / \mathrm{L} \mathrm{HCl}\end{array}$} & 1 & 0.6984 & 4.469 & 4.152 & 139.9 & 15.1172 & 15.406 \\
\hline & 2 & 0.7047 & 4.472 . & 4.203 & 146.3 & 15.6274 & 15.783 \\
\hline & 3 & 0.7035 & 4.493 & 4.358 & 152.5 & 15.7841 & 15.968 \\
\hline & 4 & 0.7002 & 4.485 & 4.181 & 140.8 & 15.1630 & 15.413 \\
\hline & 5 & 0.7103 & 4.458 & 4.176 & 147.4 & 15.7971 & 15.829 \\
\hline
\end{tabular}

$\Delta E_{s}$ : the voltage change during the sample dissolution; $\Delta E_{\mathrm{e}}$ : the voltage change during electrical calibration; $t$ : heating period of electrical calibration; $Q_{s}$ : heat effect; $\Delta_{s} H_{m}{ }^{\theta}$. dissolution enthalpy. where $Q_{s}=\left(\Delta E_{\mathrm{s}} / \Delta\right.$ $\left.E_{\mathrm{e}}\right) \cdot \mathrm{I}^{2} \mathrm{Rt}, \quad \Delta_{s} H_{m} \stackrel{\underline{\theta}}{=} Q_{s}(M / m), m$ is sample mass, $M$ isapparent molecular mass.

According to Hess' Law, the standard molar reaction enthalpy of the reaction (1) could be obtained:

$$
\Delta_{\mathrm{r}} H_{\mathrm{m}}^{\theta}(1)=\Delta_{\mathrm{s}} H_{\mathrm{m}}^{\theta}(2)+\Delta_{\mathrm{s}} H_{\mathrm{m}}^{\theta}(3)-\Delta_{\mathrm{s}} H_{\mathrm{m}}^{\theta}(4)-\Delta_{\mathrm{d}} H_{\mathrm{m}}^{\theta}(5)
$$

in which $\Delta_{\mathrm{d}} H_{\mathrm{m}}^{\theta}$ (5) is the dissolution enthalpy of water as one of the products of products of the reaction in the solvent within the experimental error and may be omitted bacause the amount of $\mathrm{H}_{2} \mathrm{O}$ is very low according to the stoichiomitric number of water.

So that $\Delta_{\mathrm{r}} H_{\mathrm{m}}^{\theta}(1)=-51.780 \mathrm{~kJ} / \mathrm{mol}$.

The evaluation of $\Delta_{\mathrm{f}} H_{\mathrm{m}}^{\theta}\left[\mathrm{Eu}(\mathrm{Gly})_{2}(\mathrm{Ala})_{3} \mathrm{Cl}_{3} \cdot 2 \mathrm{H}_{2} \mathrm{O}(\mathrm{s})\right]$ : According to thermodynamics principle, it was known that:

$$
\begin{aligned}
\Delta_{\mathrm{r}} H_{\mathrm{m}}^{\theta}= & \Delta_{\mathrm{f}} H_{\mathrm{m}}^{\theta}\left[\mathrm{Eu}(\mathrm{Gly})_{2}(\mathrm{Ala})_{3} \mathrm{Cl}_{3} \cdot 2 \mathrm{H}_{2} \mathrm{O}, \mathrm{s}, 298.15 \mathrm{~K}\right]+4 \Delta_{\mathrm{f}} H_{\mathrm{m}}^{\theta}\left[\mathrm{H}_{2} \mathrm{O}, 1,298.15 \mathrm{~K}\right] \\
& -\Delta_{\mathrm{f}} H_{\mathrm{m}}^{\theta}\left[\mathrm{EuCl}_{3} \cdot 6 \mathrm{H}_{2} \mathrm{O}, \mathrm{s}, 298.15 \mathrm{~K}\right]-2 \Delta_{\mathrm{f}} H_{\mathrm{m}}^{\theta}[\mathrm{Gly}, \mathrm{s}, 298.15 \mathrm{~K}] \\
& -3 \Delta_{\mathrm{f}} H_{\mathrm{m}}^{\theta}[\mathrm{Ala}, \mathrm{s}, 298.15 \mathrm{~K}]
\end{aligned}
$$

From the literature ${ }^{[9]}$, the following data can be obtained:

$\Delta_{\mathrm{f}} H_{\mathrm{m}}^{\theta}\left[\mathrm{H}_{2} \mathrm{O}, 1,298.15 \mathrm{~K}\right]=-285.830 \mathrm{~kJ} / \mathrm{mol}$

$\Delta_{\mathrm{f}} H_{\mathrm{m}}^{\theta}\left[\mathrm{EuCl}_{3} \cdot 6 \mathrm{H}_{2} \mathrm{O}, \mathrm{s}, 298.15 \mathrm{~K}\right]=-2788.217 \mathrm{~kJ} / \mathrm{mol}$

$\Delta_{\mathrm{f}} H_{\mathrm{m}}^{\theta}[\mathrm{Gly}, \mathrm{s}, 298.15 \mathrm{~K}]=-537.23 \mathrm{~kJ} / \mathrm{mol}$

$\Delta_{\mathrm{f}} H_{\mathrm{m}}^{\theta}[$ Ala, s, $298.15 \mathrm{~K}]=-572.57 \mathrm{~kJ} / \mathrm{mol}$

and the value worked out previously was: $\Delta_{\mathrm{r}} H_{\mathrm{m}}^{\theta}=-51.780 \mathrm{~kJ} / \mathrm{mol}$

So that $\Delta_{\mathrm{f}} H_{\mathrm{m}}^{\theta}\left[\mathrm{Eu}(\mathrm{Gly})_{2}(\mathrm{Ala})_{3} \mathrm{Cl}_{3} \cdot 2 \mathrm{H}_{2} \mathrm{O}, \mathrm{s}, 298.15 \mathrm{~K}\right]=-4488.8 \mathrm{~kJ} / \mathrm{mol}$

Validation of the themochemical cycle of reaction (1) was tested by releasing the sample cell containing the final solution from the products in the calorimeter, with no enthalpy change being detected. The UV spectrum and refractive indices of the final solution of the reactants and the final solution of the products can beused to determine if they have the same thermodynamicstate ${ }^{[10-12]}$. 


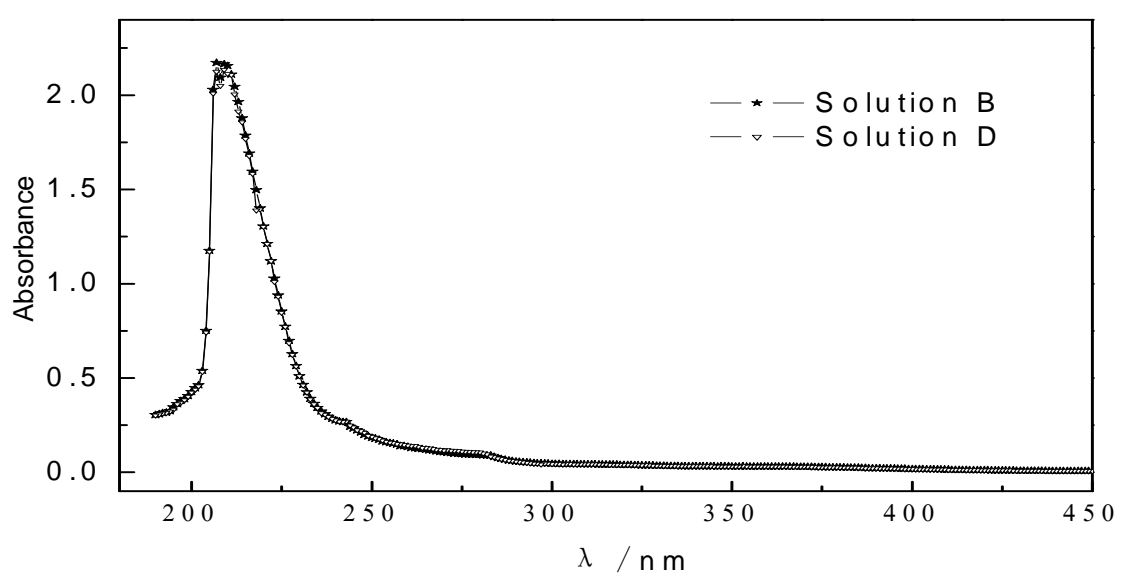

Fig. 2 UV spectrum of final dissolution state of reactants and products in $2 \mathrm{~mol} / \mathrm{L} \mathrm{HCl}$

In the present experiments, we determined the spectrum and refractive indices of solution $\mathrm{B}$ and solution D in Fig. 1. The UV-visspectrum (Fig.2) and refractive indexes $\left(\eta_{25^{\circ} \mathrm{C}}=1.3508\right)$ of solution $\mathrm{B}$ and solution $\mathrm{D}$ were identical. It proves that both have the same thermodynamic state and that the designed thermochemical cycle is reasonable and reliable. Therefore, the standard molar reaction enthalpy of the reaction (1) obtained according to Hess' Law and the standard molar enthalpy of formation of $\mathrm{Eu}(\mathrm{Gly})_{2}(\mathrm{Ala})_{3} \mathrm{Cl}_{3} \cdot 2 \mathrm{H}_{2} \mathrm{O}(\mathrm{s})$ through calculation were reliable as well.

\section{Conclusion}

On the basis of the experimental results and thermodynamic principles, the standard molar reaction enthalpy of the reaction $\mathrm{EuCl}_{3} \cdot 6 \mathrm{H}_{2} \mathrm{O}(\mathrm{s})+2 \mathrm{Gly}(\mathrm{s})+3 \mathrm{Ala}(\mathrm{s})=\mathrm{Eu}(\mathrm{Gly})_{2}(\mathrm{Ala})_{3} \mathrm{Cl}_{3} \cdot 2 \mathrm{H}_{2} \mathrm{O}(\mathrm{s})+4 \mathrm{H}_{2} \mathrm{O}(\mathrm{l})$ and the standard molar enthalpy of formation of $\mathrm{Eu}(\mathrm{Gly})_{2}(\mathrm{Ala})_{3} \mathrm{Cl}_{3} \cdot 2 \mathrm{H}_{2} \mathrm{O}(\mathrm{s})$ were evaluated to be $51.780 \mathrm{~kJ} / \mathrm{mol}$ and $-4488.8 \mathrm{~kJ} / \mathrm{mol}$ respectively.

\section{Acknowledgments}

The authors wish to acknowledge the Hunan Provincial Natural Science Foundation of China(12JJ3019) and the Scientific Research Key Fund of Hunan Provincial Education Department of China(10A113).

\section{References}

[1] L.J. Anghileri.: Arzneim Forsch.Vol.25(1975), p.793.

[2] J. Zhou; L. F. Wang; J. Y. Wang; et al.: J. Inorg. Biochem. Vol.83(2001), p.41.

[3] Y. P. Liu; J. X. Liu; Y. H. Sun; et al.: Acta Scientiarum Naturalium Universitatis Neimongol. Vol.27(1996), p.66.

[4] Z. Q. Xie.: Journal of Wuhan University(Natural Science Edition). Vol.2(1985), p.117.

[5] H. G. Yu; Y. Liu; Z. C. Tan; et al.:Thermochim. Acta.Vol.401(2003), p.217.

[6] P. Rychly; V. J. Pekarek.: J. Chem. Thermodyn. Vol.9(1977), p.39.

[7] R. L. Montgomery; R. A. Melaugh; C. C. Lan.: J.Chem. Thermodyn. Vol.9(1977), p.915.

[8] Y. X. Kong; Y. B. Li; W. W. Yang.; et al.: Acta Chimica Sinica. Vol.66(2008), p609.

[9] B.P. Liu; Z. C. Tan.: Acta Phys.-Chim Sin. Vol.29(2013), p.17.

[10] J. L. Lu; B. P. Liu; Z. C.Tan; et al.: Acta Chim. Sin. Vol.65(2007), p.2349.

[11] Y. Y. Di; Z. C. Tan; Y. S. Li.: Acta Chim. Sin. Vol.64(2006), p.1393.

[12] Y. Y. Di; Z. C. Tan; G. Q. Zhang; et al.: Thermochim. Acta. Vol.400(2003), p.43. 